\title{
In Tech we Trust? Some General Remarks on LAW IN THE TECHNOLOGICAL ERA FROM A THIRD World Perspective
}

\author{
Na Tecnologia Confiamos? Algumas \\ CONSIDERaÇÕEs ACERCa do Direito Na ERA \\ TeCnológica a Partir de UMa ABordagem \\ TERCEIRO-MUNDISTA
}

\section{¿En la Tecnología Confiamos? Algunas ObSERVACIONES Generales SOBRE El DERECHO EN la ERa Tecnológica desde Una Perspectiva del TERCER MUNDO}

\author{
José Everton da Silva* \\ Erick da Luz Scherf** \\ Marcos Vinicius Viana da Silva ***
}

1 Introduction. 2 Law and artificial intelligence: is the future already set?. 3 Robots, royalties and the new "Washington consensus": make room for progress. 4 Final considerations. References.

\footnotetext{
* PhD in Legal Sciences at UNIVALI (2016). M.A in Regional Development at FURB (2002). B.A in Law at the Federal University of Santa Maria (UFSM) (1992), Bachelor of Science at UFSM (1984). He is currently a professor at UNIVALI in the areas of Administrative Law and Intellectual Property. He is an advisor to UNIINOVA (UNIVALI) for Intellectual Property and he is the current Dean of the School for Legal and Social Sciences at the same university. Itajaí - SC - BR. E-mail: <caminha@univali.br>.http://orcid.org/0000-0003-1494-8866

** Undergraduate Student of International Relations at UNIVALI. He is a researcher in the field of Human Rights, integrating the research group entitled "Human Rights and Citizenship", registered with CNPq and the School for Legal and Social Sciences of UNIVALI. He also holds a scholarship in the community project "Intergenerational Law and Transversality: for ethnic, gender equality and social and environmental justice”. Itajaí - SC - BR. E-mail: <erickscherf@gmail.com>. http://orcid.org/0000-0002-3712-5777

*** PhD Student in Legal Sciences at UNIVALI. M.A in Legal Sciences at Univali. BA in Law at UNIVALI. Professor at the School for Legal and Social Sciences of UNIVALI in the chairs of Intellectual Property Law, International Law and Constitutional Law. Itajaí - SC - BR. E-mail:<mvsilva0805@gmail.com>. http://orcid.org/0000-0001-9026-9553
} 


\begin{abstract}
A supposed "common faith" on technology as a liberational tool has entrenched different aspects of life on society, including Law. The advancement of Artificial Intelligence (AI) promises to free the "old" and "inefficient" legal systems from their laziness and bias. However, this instrumentalist view of technology, which embraces it as a tool for the improvement of social life, seems to be an often optimistic one, and does not provide a more critical assessment on the use of AI technology in legal practice. Therefore, among the various aspects of technological advancement that can be subject of scrutiny and critique, this article intends to explore the idea of inequality, related not only to the access to the benefits from technological inventions, but also to the (in)capacity of developing these new technologies, focusing on the development and application of emerging technologies in legal systems throughout the Third World, more specifically in the region of Latin America. In sum, our conclusions were that, due to the many barriers that the countries in the periphery of the globe face in order to achieve the "greatness" of the "developed" world, when it comes to the use of AI in legal practice, for example, what is left for the Third World is to simply assume the role of consumers instead of developers. Notwithstanding, once the marginalized countries embrace the technological gifts from the "advanced" nations and reshape their traditional institutions in order for them to fit in the mold of progress, it comes at a cost no one seems to be discussing a lot about.
\end{abstract}

Keywords: Law. Technology. Artificial Intelligence. Third World.

\title{
RESUMO
}

Uma suposta "fé comum" na tecnologia enquanto uma ferramenta libertadora tem perpassado diferentes aspectos da vida em sociedade, incluindo a produção do direito. $\mathrm{O}$ avanço na Inteligência Artificial (IA) promete libertar os sistemas legais "antigos" e "ineficientes" de sua preguiça e parcialidade. No entanto, essa visão "instrumentalista" da tecnologia, que a abraça como uma ferramenta para o aprimoramento da vida social, parece ser muitas vezes otimista e não fornece uma avaliação mais crítica do uso da IA na prática legal. Portanto, entre os vários aspectos do avanço tecnológico que podem ser objeto de escrutínio e crítica, este artigo pretende explorar a ideia de desigualdade, relacionada não apenas ao acesso dos "benefícios" das invenções tecnológicas, mas também na (in)capacidade de desenvolver essas novas tecnologias, com foco no desenvolvimento e aplicação de tecnologias emergentes em sistemas legais no Terceiro Mundo, mais especificamente na região da América Latina. Em resumo, nossas conclusões foram que, devido às muitas barreiras enfrentadas pelos países da periferia do globo para alcançar a "grandeza" do mundo "desenvolvido", quando se trata do uso da IA na prática legal, o que resta para o Terceiro Mundo é simplesmente assumir o papel de consumidores em vez de desenvolvedores. No entanto, uma vez que os países 
marginalizados aceitam os presentes tecnológicos das nações "avançadas" e remodelam suas instituições tradicionais para se adequarem aos moldes do progresso, isto vem a um custo sobre o qual ninguém parece estar discutindo muito.

Palavras-chave: Direito. Tecnologia. Inteligência Artificial. Terceiro Mundo.

\section{RESUMEN}

Una supuesta "fe común" en la tecnología como herramienta liberadora ha atravesado diferentes aspectos de la vida en la sociedad, incluso la producción del derecho. El avance en la Inteligencia Artificial (IA) promete liberar a los sistemas legales "viejos" e "ineficientes" de su pereza y parcialidad. Sin embargo, esta visión "instrumentalista" de la tecnología, que la considera una herramienta para el mejoramiento de la vida social, parece ser a menudo optimista y no proporciona una evaluación más crítica del uso de la tecnología de inteligencia artificial en la práctica legal. Por lo tanto, entre los diversos aspectos del avance tecnológico que pueden ser objeto de escrutinio y crítica, este artigo pretende explorar la idea de la desigualdad, relacionada no solo con el acceso a los "beneficios" de las invenciones tecnológicas, sino también a la (in)capacidad de desarrollar estas nuevas tecnologías, enfocándose en el desarrollo y aplicación de tecnologías emergentes en sistemas legales en el Tercer Mundo, más específicamente en la región de América Latina. En resumen, nuestras conclusiones fueron que, debido a las muchas barreras que enfrentan los países de la periferia del globo para lograr la "grandeza" del mundo "desarrollado", cuando se trata del uso de la IA en la práctica legal, lo que queda para el Tercer Mundo es simplemente asumir el papel de los consumidores en lugar de los desarrolladores. No obstante, una vez que los países marginados aceptan los dones tecnológicos de las naciones "avanzadas" y remodelan sus instituciones tradicionales para que encajen en el molde del progreso, esto tiene un costo que nadie parece estar discutiendo mucho.

Palabras clave: Derecho. Tecnología. Inteligencia Artificial. Tercer Mundo.

\section{INTRODUCTION}

"Ours is the age of technology" (BAILLIE; CASEY, 2005, p. 1): a basic but powerful assumption over the moment humanity seems to be living in. And what does it mean to say that we are living in a technological era? Well, it is acknowledgeable that technology has always been a part of human life throughout history (BAILLIE; CASEY, 2005); human beings have proven to be inventive in essence. However, since technology is "the application of scientific knowledge for practical purposes, especially in the industry" (OXFORD UNIVERSITY PRESS, 2018, online), it seems to have become a determinant factor over human life, as it has never been before: "cyborgs, artificial intelligence, cloning, and genetic engineering - all are indicatives of a swiftly moving reality we struggle to make sense of in the 
absence of traditional signposts and historical precedents." (BAILLIE; CASEY, 2005, p. 1).

In his most recent book, professor Pinker-from Harvard University-designs an extensive defense of why, according to him, humanity is living in a new era of Enlightenment, and why this is to be considered a good instead of a bad thing (PINKER, 2018, p. 1-6). As stated by Pinker, "more than ever, the ideals of reason, science, humanism, and progress need a wholehearted defense." (PINKER, 2018, p. 4). The professor believes that thanks to science and technology, humanity has gained gifts it could not receive from "cosmic birthrights": such as long-life expectancy, food and drinking water availability, medication and even access to information, all of them products of "human reason" (PINKER, 2018, p. 1-6).

Of course, no one can deny the fact that it was due to human inventiveness and constant advancement in science and its applications that we were able to control the many sores that have once tackled human life on Earth. To professor Jasanoff: "technological innovations account for the trend; better sanitation, drinkable water, vaccines, antibiotics, and more abundant and wholesome food" (JASANOFF, 2016, p. 2), amongst other benefits that humans have at their disposal to guarantee a life with more quality and less suffering. With that said, one is hardly able to prove (even with numbers and statistics) that humanity has gotten rid-once and for all_of the problems it has fought to eliminate for thousands of years: such as starvation, epidemics and violence (in its many forms).

What humanity has come to achieve is not the eradication of the so-called major problems of human civilization: "these problems have not been completely solved, but they have been transformed from incomprehensible and uncontrollable forces of nature into manageable challenges." (HARARI, 2017, p. 1-2). This therefore created a state of mind, descendant from the idea that professor Pinker defends in his book, that human reason expressed through science is the only way we can lead humanity to a brighter future. Which also has led us to think of technology as a "dream of liberation", in the words of professor Jasanoff, in a sense that technology is portrayed as a solid tool that we have clear control over and consequently are able to utilize in order to improve various aspects of human life in the world, including humans themselves (JASANOFF, 2015, p. 1-33).

This supposed "common faith" on technology as a liberational tool has entrenched different aspects of life on society, including Law. The advancement of Artificial Intelligence (AI), for example, brings hopes of "improvement [...] both in how our laws are applied and how they are written" (TEGMARK, 2017, p. 137), and it also promises to constantly decrease the role of lawyers in legal processes of all kind: "an artificial intelligence technique called natural language processing has proved useful in scanning and predicting what documents will be relevant to a case, for example" (LOHR, 2017, online), as well as replacing traditional magistrates for "robotjudges", applying "the same high legal standards to every judgment without succumbing to human errors such as bias, fatigue or lack of the latest knowledge" (TEGMARK, 2017, p. 137). 
As luminous as these ideas might seem, "technological civilization [...] is not just a bed of roses" (JASANOFF, 2016, p. 4). This instrumentalist view of technology, which embraces it as a tool, "an instrument of the social, political, or economic group or individual that chooses to develop and use a certain technology" (COCKFIELD; PRIDMORE, 2007, p. 479-480), seems to be often optimistic about the uses of technology in society and ends up being "the most widely accepted view of [it]" (COCKFIELD; PRIDMORE, 2007, p. 480). However, this linear and triumphalist view lacks the sense of critique necessary to evaluate the negative results of the uses of technology in society, especially in legal systems.

"The notion that society should assess the desirability of technologies is fairly recent." (LUCIVERO, 2016, p. 5). For a very long time "society trusted scientists who worked according to a mandate in order to contribute to social progress." (LUCIVERO, 2016, p. 5). This resulted from sociotechnical imaginary institutions that conceived technology apart from social arrangements that inspire and sustain its production, which requires us to bring "social thickness and complexity back into the appreciation of technological systems." (JASANOFF, 2015, p. 3).

It does not mean that we should hate technology or imply an analysis that looks for angels or demons, instead, the "ultimate goal is to destroy the ideology of technology, so that particular technologies can be used in specific situations" (MADRIGAL, 2013, online), without taking science and technology as religions that should not be contested (GEE, 2013).

Among the various aspects of technological advancement that can be subject of scrutiny and critique, this article intends to explore the idea of inequality, related not only to the access of the "benefits" from technological inventions, but also to the (in) capacity of developing these new technologies, focusing on the development and application of emerging technologies in legal systems throughout the Third World.

The "Third World" category clearly needs a defense before continuing into the next steps of this paper. This is so because many might find this expression outdated or inadequate, since it was essentially created in reference to the Cold War time, when there was a "tripartite division of the world into capitalist, communist, and non-aligned blocs" (RAO, 2010, p. 24). However, as professor Rahul Rao profoundly examines in his book, "Third World' was not a place but a political project pursued by a group of recently decolonized States between the mid-1950s and the early 1980s, aimed at mitigating interstate inequality in the international system." (RAO, 2010, p. 25).

Although this political project might not exist in the same way it did in the Cold War times, "there is still the old impassioned defence of sovereignty and territorial integrity [...] demands for fairer terms of trade, more aid, debt cancellation, and above all equity in issue areas as varied as climate change [...] [,] nuclear proliferation" (RAO, 2010, p. 27), and of course in the access to technology consumption and production.

In this sense, when one is to talk about the Third World perspectives relating to the future of Law in the technological era, they do so in hope of demystifying "the shift in ter- 
minology [which] seemed to obscure the hierarchical relationship between rich and poor by re-presenting them in apparently egalitarian spatial terms" (RAO, 2010, p. 26), showing that "people experience [technology] differently, depending on where they live, how much they earn, how well they are educated, and what they do for a living" (JASANOFF, 2016, p. 5), different from what many scholars defend, that is, that technology is universal and consequently ubiquitous.

\section{LAW AND ARTIFICIAL INTELLIGENCE: IS THE FUTURE ALREADY SET?}

The intersection between Law and Technology seems to be a very attractive one nowadays, and in being so, many authors have dedicated time and effort to try to understand the limits and potentialities of integrating these two areas. The contribution of this research paper is to make us think about the future of legal practice in the technological era from a Third World perspective. So, what we intended was to look for what is missing in the discourse of technological triumphalism in the sense that what appears to us is that the tech world already exists and we have no other option but embrace it, what clearly masks important inequalities regarding the access, development and even the will to use technological tools applied to legal systems in the periphery of the world.

The uses of technology in Law can be really diverse: from an app that searches for jurisprudence to a platform for intelligent document automation, technology seems to be shifting the future of legal practice. In this case, Artificial Intelligence (AI) applied to legal issues is apparently the most prominent field. For example, computer scientists at University College London (UCL) are developing an AI software capable of examining legal evidence and reaching out to moral questions of "right" and "wrong" in highly complex cases (JOHNSTON, 2016), and "the AI 'judge' has reached the same verdicts as judges at the European Court of Human Rights in almost four out of five cases involving torture, degrading treatment and privacy." (JOHNSTON, 2016, online).

If one makes a quick search in any online bookstore for titles containing the words "Artificial Intelligence", many results will pop out, but among the diversity of books, one is to realize the spirit of technological determinism most of these titles carry with them, consciously or not, for example (in no specific order): "Life 3.0: Being Human in the Age of Artificial Intelligence"; "Our Final Invention: Artificial Intelligence and the End of Human Era", "The Sentient Machine: The Coming Age of Artificial Intelligence", among others. So, it is what it is, right? AI is the future of humanity, and subsequently the future of any social arrangement, including Law, and our role as citizens is simply to trust that "intelligent machines [...] will create a paradise for humanity" (GERACI, 2010, p. 1).

If it is agreed that the fate of humanity is already set, and that humans will have to give room for AI to replace them in various (previous) human activities, little room is left for ethics or regulation policies regarding emerging technologies. This discourse seems to be giving life to technology apart from social or cultural contexts, as if it was an uncontrollable 
force of nature: "the structure of such popular narratives conveys a vivid sense of the efficacy of technology as a driving force of history: a technical innovation suddenly appears and causes important things to happen" (SMITH; MARX, 1994, p. 10), therefore, "[the] sense of technology's power as a crucial agent of change has a prominent place in the culture of modernity." (SMITH; MARX, 1994, p. 9).

However, this discourse of (AI) technology as a driving force of history is missing some important categories of analysis. One of them is imagination: professor Jasanoff defined well the importance of imagination through the concept of "sociotechnical imaginary institutions", which are "collectively held, institutionally stabilized, and publicly performed views of desirable futures, animated by shared understandings of forms of social life and social order attainable through, and supportive of, advances in science and technology." (JASANOFF, 2015 , p. 4). This means that AI will only take over courtrooms around the world if it finds social forces willing to embrace it and invest on it. In sum, what is important here is to put down "the belief that social progress is driven by technological innovation, which in turn follows an 'inevitable' course." (SMITH, 1994, p. 38).

The notion of "technopoly", defended by Neil Postman in 1992, could not be a more quotable one, even after 26 years of constant revolutions on science and technology. Technopoly emerges from the concept of technocracy, which gives us "the idea of progress and necessity to loosen our bonds with tradition - either politically or spiritually." (POSTMAN, 1992, p. 45). Technopoly, subsequently "is [a] totalitarian technocracy", that redefines "what we mean by religion, art, family, politics, history, truth, privacy, intelligence, so that our definitions fit [in] its new requirements." (POSTMAN, 1992, p. 48). In this sense, when one says that Law as we know it is destined to disappear, they are clearly subjugating social and cultural institutions to the "greater good" of technological advancement.

Let's take for example a country in West Africa: Sierra Leone. The Republic of Sierra Leone has a mixed legal system of English common law and customary law. Since the "democratization" of a large number of African countries after the end of the Cold War period, justice systems have spread all over the region, including in Sierra Leone. The country has a "dual" legal system, in a sense that there is a general law, which is called "the formal system", which includes the Constitution and laws made by the Parliament, and on the other hand there is an institutionalized customary law system, which is indeed recognized by the Constitution (1991) (CORRADI, 2010, p. 73-103).

However, the high courts that compose "the formal system" are almost inaccessible due to geographical distance and elevated costs, consequently, "about $85 \%$ of Sierra Leoneans fall under the jurisdiction of customary law [...] 'Local courts' [that] are formally and legally empowered to hear and determine cases involving customary law issues in the provinces." (CORRADI, 2010, p. 77).

In this sense, the idea_defended by a large number of authors — of AI taking over legal systems around the world is just reinforcing the notion of technopoly when it takes 
for granted the role that historical societal and cultural institutions exercise in the composition of justice systems in different countries. Thus, what some people assume is that the incorporation of technological innovations in legal practice is the best for any society at any time, regardless of its current institutional practices. Traditional justice systems such as the one in Sierra Leone are often portrayed as being slow, outdated and inefficient, therefore, they should be open to improvement and betterment, which can only be achieved with the blessings of technology.

By analyzing Postman's argumentation about the ideology of computer technology, if one replaces the word "computer" by "AI technology", it is possible to see the persistent appeal to a universality of the tech world, regardless of any tradition or cultural background: "the "universality" of [AI technology], mean[s] that [its] uses are infinitely various" (POSTMAN, 1992, p. 107). Consequently, AI is seen as ubiquitous, suitable to any place or time. It is not a problem in terms of cultural relativism, in a sense that an existing practice or institution in a society should not be subject to change in order to maintain the cultural background of that community, the problem with technology universalism is that it is in fact an internationalism from a localism, similar to globalization.

Professor Boaventura suggests that the discourse about globalization is the history of the winners, told by no one but themselves: "globalization is the process by which a certain condition or local entity is able to extend its influence worldwide, and in doing so, it develops the capacity of designating itself as local as another social condition or rival entity" (SANTOS, 1997, p. 108, our translation). In this sense, some local achievements by some specific societies (definitely not those in the Third World) are considered as being "universal", mainly because they get to tell the story of what is universal or not. The same happens to technology and its applications in legal practice.

A group of scientists, students or corporate entities come up with a technological innovation in a very specific social context and, all of a sudden, the fate of the rest of the world is settled. But the recipients of these technological advancements do not see their culture or traditions being ripped out in front of them: "technocracy [does] not entirely destroy the traditions of the social and symbolic worlds. Technocracy subordinate[s] these worlds-yes, even humiliate [s] them-but it did not render them totally ineffectual" (POSTMAN, 1992, p. 45). Consequently, it becomes even more difficult to enunciate the impacts of choosing tech institutions instead of cultural and social stablished ones.

Notwithstanding, the case for cultural and social traditions is definitely not strong enough to confront the ideology of technology, especially in a "liquid" world where people define and redefine their identities with the flip of a screen. One of the strongest arguments in favor of AI use in legal practice is that of bias: "one day, such robotjudges may therefore be both more efficient and fairer, by virtue of being unbiased, competent and transparent" (TEGMARK, 2017, p. 138), "legal history is rife with judgments biased by skin color, gender, sexual orientation, religion, nationality and other factors. Robotjudges could in principle 
ensure that, for the first time in history, everyone becomes truly equal under the law." (TEGMARK, 2017, p. 138).

How could one not be moved by these propositions? The discourse of AI eliminating bias in legal processes promises to serve all humans with the dignity that some have never witnessed due to a personal or social characteristic. However, when machines assume an essentially human aspect, assuming positions of command and control, they help bureaucrats "create the illusion that decisions are not under their control" (POSTMAN, 1992, p. 115):

Because of its seeming intelligence and impartiality, a [robot] has an almost magical tendency to direct attention away from the people in charge of bureaucratic functions and toward itself, as if the [robot] was the true source of authority. A bureaucrat armed with a [robot] is the unacknowledged legislator of our age, and a terrible burden to bear. We cannot dismiss the possibility that, if Adolf Eichmann had been able to say that it was not he but a battery of computers that directed the Jews to the appropriate crematoria, he might never have been asked to answer for his actions (POSTMAN, 1992, p. 115).

Imagine how one could contest the decision of a robotjudge? If one loses in a lower court and wants to take their case further to a higher court, such as the Supreme Court of any given country, what would be the point if the justice robot would probably give the same verdict? Who is in charge then of reviewing the decisions of these robotjudges? Another robot? Who is going to guarantee that the demands of justice will be fulfilled in every robot-led-trial? Well, it is acknowledgeable that the "traditional" justice system (sponsored by human beings) is far from perfect, however, no one seems to be contesting the injustices that could occasionally happen in an artificial intelligent courtroom, which reiterates the "omnipotence that characterizes the religion of technology." (NOBLE, 1995, p. 129).

In sum, what is frequently preached is that the world of AI is going to cause a revolution in legal practice and that there is nothing to do but to accept it. The ideology of technology therefore makes us believe that apart from any social, cultural or imaginary background, the use of AI in courtrooms and other places is what the future reserves us, and if one is willing to see an improvement in an "old" and "inefficient" legal system, they should make room for robotjudges free from bias and laziness. However, this discourse seems not to be far away from the one defending globalization, by which a minority of the world is able to put up its accomplishments as "universal". The consequences of embracing this discourse in the Third World shall be discussed in the next section of this study.

\section{ROBOTS, ROYALTIES AND THE NEW “WASHINGTON CONSENSUS": MAKE ROOM FOR PROGRESS}

The reason why we have chosen to talk about Third World, instead of using the expression "developing countries", is because "the original connotations of 'Third World' are [...] far more attractive than those of 'developing', which suggests a slavish, unimaginative teleology in which developing States strive to resemble the developed ones" (RAO, 2010, p. 25). 
In this sense, when talking about Law in the technological era, the "developing" category serves to propagate the rhetoric that the Third World countries are aiming to being able one day to have access and to make use of the wonderful technological innovations that the developed countries can provide them with, what is not necessarily true. Hence, the original idea of Third World, of non-alignment and denunciation of the hierarchies of global economy (RAO, 2010, p. 1-34) has much to add to a more critical approach to the use of technology in legal practice.

The region that we intend to focus on going forward is Latin America. Mainly because "Latin American States [...] [still] possess [...] characteristics of Third Worldness (great economic and social disparities, dependent development, and marginalization from the core of international society) in a sufficient degree to qualify for membership." (RAO, 2010, p. 29).

The World Bank has recently released a book entitled "The Jobs of Tomorrow: Technology, Productivity, and Prosperity in Latin America and the Caribbean". More specifically, through chapter 2-named "The Need for Productivity-Enhancing Technology Adoption in Latin America and the Caribbean" (our italics) - one can clearly see the spirit of technological ideology in a sense that the region of Latin America and the Caribbean (LAC) is portrayed as belated for not having the same level of digital technologies as its peers from the "developed" world (DUTZ; ALMEIDA; PACKARD, 2018).

"Even in the wealthiest, institutionally most advanced LAC countries, digital technology adoption by households and businesses is well below that of peer countries and members of the OECD." (DUTZ; ALMEIDA; PACKARD, 2018, p. 14). Thus, the region immediately needs to "tech up" its game in order to maybe-one-day achieve the status of the greatest nations of the North.

This idea of a "necessity" of the Latin American countries to follow the economic, social and technological steps of the "developed" nations is far from new, but it became crystal clear through what came to be known as the "Washington Consensus". The term was first used in 1989, in a conference held by the Institute for International Economics, that intended "[...] to examine the extent to which the old ideas of development economics that had governed Latin American economic policy since the 1950s were being swept aside by the set of ideas that had long been accepted as appropriate within the OECD." (WILLIAMSON, 2008, p. 14).

"Proponents of the Washington Consensus argue that the original conception had three big ideas: a market economy, openness to the world, and macroeconomic discipline." (SERRA; STIGLITZ, 2008, p. 1). Therefore, according to the propositions from the "Washington agenda", the countries of Latin America would conquer economic growth and subsequently the realization of the American dream. However, those countries that cooked the magical recipe for development handled by Washington in the 1990s, did not necessarily achieve the "developed stage" as expected: 
In the countries that followed Washington Consensus policies, economic growth was limited at best, and disproportionately benefited those at the top. In Latin America, for example, seven years of strong growth in the early 1990s were followed by seven years of stagnation and recession, so that for the period as a whole, growth under the Washington Consensus was half of what it had been from the 1950s through the 1970s when the region followed other economic policies, such as import substitution. Even in countries where Washington Consensus policies did appear to promote growth, such growth was often not accompanied by significant reductions in poverty (SERRA; STIGLITZ, 2008, p. 14).

It is possible then to acknowledge the dangers of accepting an "universal" recipe in any social or economic area regardless of a country/region specific needs and characteristics, and it could not be different with technology application. How long is it going to take until a new "Washington Consensus" is formed (by the "developed countries") to discuss the "backwardness" of Latin American justice systems in relation to the technological advancements accomplished by the "most advanced" States of the globe? What is the recipe going to be this time, a "need" for a massive acquisition of AI technology with applications in legal practice? What are going to be the conditions under which Latin American countries will acquire this new technology to "improve" their old and inefficient legal systems?

Out of the seven countries that are in a "race to rule the world with AI", according to Forbes Magazine (MINEVICH, 2017), none of them is in Latin American. In the United States alone there are 850,000 AI professionals, which indicates that the country is investing really hard to become a global leader in automation(MINEVICH, 2017). And what is left then to Latin American countries in the "Global Value Chains (GVCs)"1 of Artificial Intelligence?

Brazil, for example, is the main recipient of Foreign Direct Investment (FDI) in the region of Latin America and the Caribbean (47\% of the total) and the investments in the country increased by $5.7 \%$ by the year of 2017 (BÁRCENA, 2017, p. 12). Meanwhile, Mexico remained the second largest host country (19\%) (BÁRCENA, 2017, p. 12). This is a common characteristic to be found in Third World countries after the "globalization" of market economy. Since the 1980s, "LAC countries began liberalizing their development strategies. Governments in the region, for example, have integrated their economies with the global economy by reducing trade barriers, privatizing state-owned enterprises, and removing controls on prices and capital accounts." (WILLIAMS, 2015, p. 57).

However, the countries that are hosts to these FDIs do not necessarily acquire the same value in the GVCs, in fact, they usually are the ones that profit the less in the whole process, which can be explained by the concept of the "smile curve" (see Figure 1): the

1 According to the OECD: "International production, trade and investments are increasingly organised within the so-called global value chains (GVCs), where the different stages of the production process are located across different countries. Globalisation motivates companies to restructure their operations internationally through outsourcing and offshoring of activities." (OECD, 2018). 
concept of the smile curve was first used in 1992 by Stan Shih, the founder of Acer, "[he] observed that in the personal computer industry, both ends of the value chain command higher values added to the product than the middle part of the value chain" (YE; MENG; WEI, 2015, p. 2-3).

Figure 1 - Smile curve representation

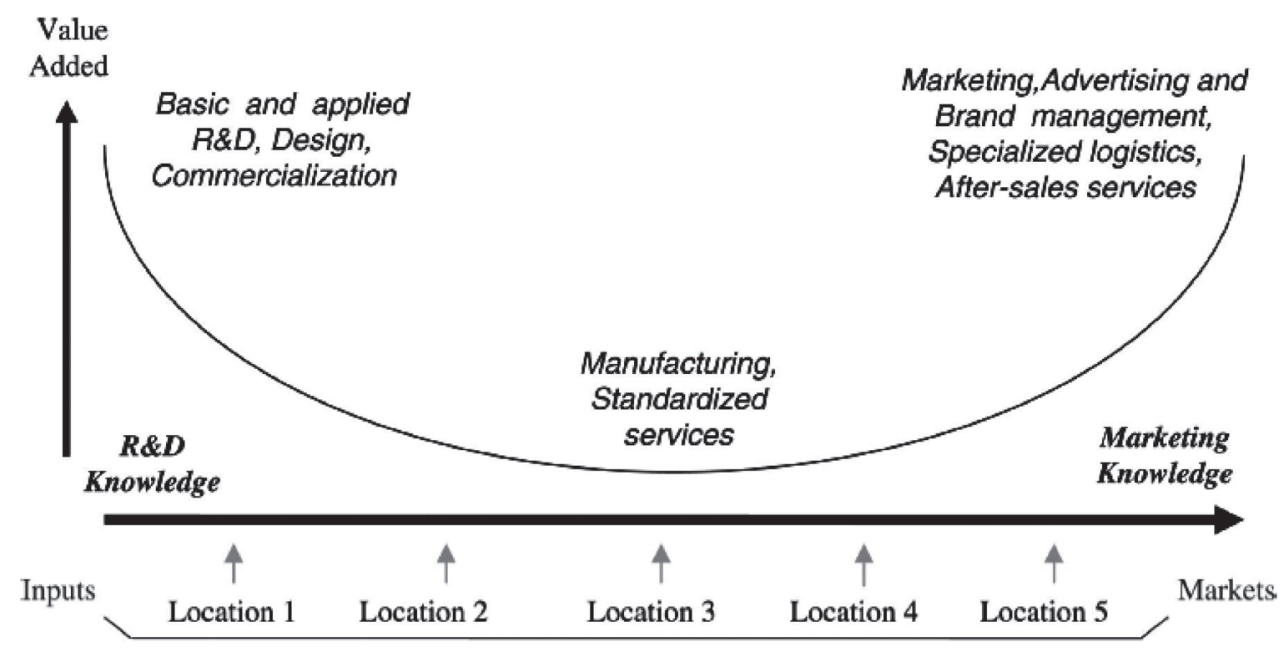

SOURCE: (YE, MENG; WEI, 2015, p. 2-3).

In this sense, most if not all of Latin American countries fall in the low end of the curve when talking about the GVCs of AI technology, as well as other technologies in general. The actual rewards go to those countries that have invested in the research and development of these technological innovations, i.e., those that own the intellectual property rights over their creations, rights that are usually earned by patent systems. As well as those responsible for the branding tend to occupy higher positions in the curve. The countries (most commonly the "developing" ones) that are receptacles to the manufacture plants and subsidiaries in general can hardly improve their competitiveness in the curve (YE; MENG; WEI, 2015, p. 3 ), due to the fact that they share an "unequal access to technological progress" (MAKAREWICZ-MARCINKIEWICZ, 2013, p. 67).

The fairy tale told by the ones in the high spots of the curve is that the poor States from below would benefit from technology transfer through local learning, however, the reality is that the most "technologically advanced" countries become "richer and increase the distance to those that do not have access to new technologies. Only a small number of developed countries may allocate sufficient funds for research and development. For the less developed countries, there is only one option left: obtaining access." (MAKAREWICZ-MARCINKIEWICZ, 2013, p. 70).

This paradigm, consequently, is persistent in the technological tools applied to legal systems across the Third World. In Brazil, for example, the enterprises providing products and 
services in legal technologies, known as "Lawtechs", are all practically foreign companies. ${ }^{2}$ In fact, the country invests only $0.01 \%$ of its total Gross Domestic Product (GDP) on Artificial Intelligence research and development (SEBRAE, 2018), which expresses how far Brazil and Latin America in general are from developing their own technological tools applicable to legal practice. In this sense, if the region is to embrace the "future" of Law through the use and application of AI innovations in legal processes, it has to bear in mind that it will come at a cost that will have to be paid to those fortunate enough to have the capabilities of developing and increasing constantly these emerging technologies.

Michele Boldrin and David K. Levine have extensively defended in their book the idea that the modern system for Intellectual Property (IP) protection can be characterized as an intellectual monopoly that is not necessary to boost innovation: "the basic conclusion of this book is that intellectual monopoly-patents, copyrights, and restrictive licensing agreements - are unnecessary [...] Most innovations have taken place without the benefit of intellectual monopoly." (BOLDRIN; LEVINE, 2008, p. 15).

The authors argue that monopoly in general serves only "to transfer wealth away from the rest of society and toward [the owners]" (BOLDRIN; LEVINE, 2008, p. 69). In sum, "the theory of why IP-efficiency comes about is rather simple: like every profit maximizing entrepreneur, monopolists are willing and able to do anything legally and technically feasible to retain their monopoly profits." (BOLDRIN; LEVINE, 2008, p. 69).

The IP system serves then as another restraint to the countries in the Third World that would desire to develop their own technological innovations with applications in legal issues, since they do not possess the same capabilities and know-how necessary to the exploration of new cutting-edge technological tools. Hence, the "developed" countries capable of investing heavily in research and development of new technologies arrive first at the finish line and guarantee themselves the right to monopolize these inventions.

With the growing regime for the protection of IP rights, through the adoption of the 1994 Agreement on Trade-Related Aspects of Intellectual Property Rights (TRIPS) administered by the World Trade Organization (WTO), as well as the creation of the Intellectual Property Committee (IPC) (SELL, 2013, p. 1-29), the interests of private sector actors entered with full force in the global politics: "these private sector actors succeeded in getting most of what they wanted from a global IP agreement, which now has the status of public international law." (SELL, 2013, p. 2). Which reinforces the growing gap of state regulation over issues of essentially public interest, such as the frontiers of technological advancement.

In sum, the Third World countries are always portrayed as being in a lower stage of technological civilization, and it could not be different when it comes to the use of technology in legal matters. As they have no capability whatsoever to develop their own technological innovations with applicability in law (due to many factors, including IP protection systems

2 See: (ASSOCIAÇÃO BRASILEIRA DE LAWTECHS E LEGALTECHS, 2017). 
and technological exclusion in general), they have to make room for the progress that comes in the form of a robotjudge imported from the "developed" countries, and this is the only way of getting rid of the old burdens of traditional justice systems.

This narrative subjugates the cultural and social institutions as well as the sociotechnical imaginary ones of the Third World in detriment of the greater good of technological advancement, so it has now passed the time for analysts and scholars to start developing a more critical assessment to the role of emerging technologies in the legal systems of those countries pushed to the margins of international society.

\section{FINAL CONSIDERATIONS}

Technology seems to be a defining characteristic of human life in the present and the promises are that it will be an even more shifting aspect of life in the future. This discourse by which technology is portrayed as a driving force of history has been contested before, however, this instrumentalist and triumphalist view of technological advancement has gained actually more friends than enemies nowadays, and it could not be different when talking about the future of Law in the technological era.

Among the various aspects of technological advancement that could be subject of scrutiny and critique, this article intended to explore the idea of inequality, related not only to the access to the "benefits" from technological inventions, but also to the (in) capacity of developing these new technologies, focusing on the development and application of emerging technologies in legal systems throughout the Third World.

The uses of technology in Law can be really diverse, especially when talking about Artificial Intelligence, therefore, technological tools are frequently drawn as being universal, despite of any cultural, social institution or a sociotechnical imaginary one. However, this universalist view serves only for the purpose of internationalizing the interests of a few privileged actors in global politics who detain the resources and the rights to develop and explore emerging technologies.

Hereinafter, a narrative is constructed by those "developed" countries by which the Third World is depicted as being in a delayed stage of the technological civilization. The justice systems of Third World nations are considered to be full of bias and laziness, hence, they should open space for technological progress expressed through the many uses of technology in legal issues.

Due to the many barriers that the countries in the periphery of the globe face in order to achieve the "greatness" of the "developed" world, when it comes to the use of AI in legal practice, for example, what is left for the Third World is to simply assume the role of consumers instead of developers. Notwithstanding, once the marginalized countries embrace the technological gifts from the "advanced" nations and reshape their "traditional" institutions in order for them to fit in the mold of progress, it comes at a cost no one seems to be discussing a lot about. 
In this sense, the countries in the Third World become merely recipients of the technological advancements achieved by those that have the capabilities of developing and increasing constantly the various technological innovations at their disposal. Therefore, one has to bear in mind that, if the Third World wants to embrace the "future" of Law through the use and application of AI innovations in legal processes, it has to be aware not only of the "benefits" of this magical recipe for progress, but of the negative consequences that might come attached to it as well.

\section{REFERENCES}

ASSOCIAÇÃO BRASILEIRA DE LAWTECHS E LEGALTECHS. O mapa das Lawtechs e Legaltechs no Brasil. 2017. Available at: < https://www.ab2l.org.br/o-mapa-daslawtechs-e-legaltechs-no-brasil-ab2l/> . Access on: 20 July 2018.

BAILLIE, Harold W.; CASEY, Timothy K. Introduction. In: BAILLIE, Harold W.; CASEY, Timothy K. (Ed.). Is Human Nature Obsolete?: genetics, bioengineering, and the future of the human condition. Cambridge: Massachusetts Institute of Technology, 2005. p. 1-32.

BÁRCENA, Alicia et al. Foreign Direct Investment in Latin America and the Caribbean: 2017. Santiago: United Nations, 2017.

BOLDRIN, Michele; LEVINE, David K. AGAINST INTELLECTUAL MONOPOLY. Cambridge: Cambridge University Press, 2008.

COCKFIELD, Arthur; PRIDMORE, Jason. A synthetic theory of law and technology. Minnesota Journal of Law, Science \& Technology, v. 8, n. 2, p. 475-513, Jan. 2007. Available at: $<$ https://scholarship.law.umn.edu/cgi/viewcontent.cgi?article $=1258 \&$ conte $\mathrm{xt}=$ mjlst $>$. Access on: 16 July 2018.

CORRADI, Giselle. Human Rights Promotion in Post Conflict Sierra Leone: Coming to Grips with Plurality in Customary Justice. The Journal of Legal Pluralism and Unofficial Law, v. 42, n. 60, p. 73-103, jan. 2010. Available at: <http://commission-on-legal-pluralism.com/volumes/60/corradi-art.pdf >. Access on: 20 July 2018.

DUTZ, Mark A.; ALMEIDA, Rita K.; PACKARD, Truman G. The Jobs of Tomorrow: Technology, Productivity, and Prosperity in Latin America and the Caribbean. Washington: The World Bank, 2018.

GEE, Henry. Science: the religion that must not be questioned. 2013. Available at: $<$ https://www.theguardian.com/science/occams-corner/2013/sep/19/science-religion-notbe-questioned >. Access on: 16 July 2018.

GERACI, Robert M. Apocalyptic ai: views of heaven in robotics, artificial intelligence, and virtual reality. Oxford: Oxford University Press, 2010. 
HARARI, Yuval Noah. Homo Deus: a brief history of tomorrow. New York: HarperCollins, 2017.

JASANOFF, Sheila. Future imperfect: science, technology, and the imaginations of modernity. In: JASANOFF, Sheila; KIM, Sang-Hyun (Ed.). Dreamscapes of Modernity: sociotechnical imaginaries and the fabrication of power. Chicago: University of Chicago Press, 2015.

JASANOFF, Sheila. The ethics of invention: technology and the human future. New York; London: W.W. Norton \& Company, 2016.

JOHNSTON, Chris. Artificial intelligence 'judge’ developed by UCL computer scientists. 2016. Available at: <https://www.theguardian.com/technology/2016/oct/24/artificial-intelligence-judge-university-college-london-computer-scientists $>$. Access on: 18 July 2018.

LOHR, Steve. A.I. Is doing legal work: but it won't replace lawyers, yet. 2017. Available at: <https://www.nytimes.com/2017/03/19/technology/lawyers-artificial-intelligence. html $>$. Access on: 16 July 2018.

LUCIVERO, Federica. Democratic appraisals of future technologies: integrating ethics in technology assessment. In: LUCIVERO, Federica. Ethical Assessments of Emerging Technologies: appraising the moral plausibility of technological views. New York: Springer, 2016. p. 3-36.

MADRIGAL, Alexis C. Toward a Complex, Realistic, and Moral Tech Criticism. 2013. Available at: <https://www.theatlantic.com/technology/archive/2013/03/toward-a-complex-realistic-and-moral-tech-criticism/273996/>. Access on: 16 July 2018.

MAKAREWICZ-MARCINKIEWICZ, Agnieszka. Strategies Against Technological Exclusion: The Contribution of the Sustainable Development Concept to the Process of Economic Inclusion of Developing Countries. Problems of Sustainable Development, [S.1.], v. 8, n. 2, p. 67-74, ago. 2013. Available at: <https://goo.gl/owgysW>. Access on: 20 July 2018.

MINEVICH, Mark. These Seven Countries Are In A Race To Rule The World With AI. 2017. Available at: <https:/www.forbes.com/sites/forbestechcouncil/2017/12/05/these-sevencountries-are-in-a-race-to-rule-the-world-with-ai/\#fa7201c4c245>. Access on: 20 July 2018.

NOBLE, David F. Progress without people: new technology, unemployment, and the message of resistance. Toronto: Between The Lines, 1995.

OECD. Global Value Chains (GVCs): 2018. Available at: < https:/www.oecd.org/sti/ind/ global-value-chains.htm>. Access on: 20 July 2018.

OXFORD UNIVERSITY PRESS. Oxford Living Dictionaries: Definition of technology in English. 2018. Available at: < https://en.oxforddictionaries.com/definition/technology $>$. Access on: 16 July 2018. 
PINKER, Steven. Enlightenment Now: the case for reason, science, humanism, and progress. New York: Viking, 2018.

POSTMAN, Neil. Technopoly: The Surrender of Culture to Technology. New York: Alfred A Knopf, 1992.

RAO, Rahul. Introduction. In: RAO, Rahul. Third World Protest: Between Home and the World. Oxford: Oxford University Press, 2010. p. 1-34.

SANTOS, Boaventura de Souza. Uma concepção multicultural de direitos humanos.

Lua Nova, São Paulo, n. 39, p. 105-124, 1997. Available at: <http://www.scielo.br/scielo. php? script $=$ sci_arttext\&pid $=$ S0102-64451997000100007\&lng $=$ en $\& n r m=i s o>$. Access on: 20 July 2018.

SEBRAE. As vantagens de investir no mercado de Inteligência Artificial. 2018. Available at: <http://blog.sebrae-sc.com.br/vantagens-de-investir-no-mercado-de-inteligencia-artificial/>. Access on: 20 July 2018.

SELL, Susan K. Private Power, Public Law: The Globalization of Intellectual Property Rights. Cambridge: Cambridge University Press, 2003.

SERRA, Narcís; STIGLITZ, Joseph E. (ed.). The Washington Consensus Reconsidered: Towards a New Global Governance. Oxford: Oxford University Press, 2008.

SMITH, Merritt Roe; MARX, Leo (Ed.). Does Technology Drive History?: the dilemma of technological determinism. Cambridge: Massachusetts Institute of Technology, 1994.

SMITH, Michael L. Recourse of empire: landscapes of progress in technological America. In: SMITH, Merritt Roe; MARX, Leo (Ed.). Does Technology Drive History?: the dilemma of technological determinism. Cambridge: Massachusetts Institute of Technology, 1994. p. 37-52.

TEGMARK, Max. Life 3.0: being human in the age of artificial intelligence. New York: Alfred A. Knopf, 2017.

WILLIAMS, Kevin. Foreign direct investment in Latin America and the Caribbean: An empirical analysis. Latin American Journal of Economics, [S.1.], v. 52, n. 2, p.57-77, 18 May 2015. Available at: <https://scielo.conicyt.cl/pdf/laje/v52n1/art03.pdf>. Access on: 20 July 2018.

WILLIAMSON, John. A Short History of the Washington Consensus. In: SERRA, Narcís; STIGLITZ, Joseph E. (ed.). The Washington Consensus Reconsidered: Towards a New Global Governance. Oxford: Oxford University Press, 2008. p. 14-30.

YE, Ming; MENG, Bo; WEI, Shang-jin. IDE DISCUSSION PAPER No. 530: Measuring Smile Curves in Global Value Chains. 2015. Available at: < http://rigvc.uibe.edu.cn/ docs/20160329210052329340.pdf>. Access on: 20 July 2018. 